Check for updates

Cite this: RSC Adv., 2017, 7, 39221

Received 15th July 2017

Accepted 1st August 2017

DOI: 10.1039/c7ra07803j

rsc.li/rsc-advances

\section{Valorization of an underused sugar derived from hemicellulose: efficient synthesis of 5- hydroxymethylfurfural from mannose with aluminum salt catalyst in dimethyl sulfoxide/water mixed solvent $\uparrow$}

\begin{abstract}
Songyan Jia, (D) *a Xinjun $\mathrm{He}^{\mathrm{a}}$ and Zhanwei $\mathrm{Xu}^{\mathrm{b}}$
Converting saccharides into 5-hydroxymethylfurfural (5-HMF) has attracted more and more research interest under the background of global energy shortage. A lot of effort has been devoted to the conversion of fructose and glucose. However, other underused sugars receive very limited attention, although some of them have considerable reserves in nature as well. In this work, mannose, a major component from hemicellulose, was effectively converted into 5-HMF under mild conditions. $\mathrm{AlCl}_{3} \cdot 6 \mathrm{H}_{2} \mathrm{O}$ exhibited superior activity among the tested catalysts, achieving a maximum 5- $\mathrm{HMF}$ yield of $60 \%$ in a dimethyl sulfoxide (DMSO)/water mixed solvent at $130{ }^{\circ} \mathrm{C}$ within $45 \mathrm{~min}$. Adding an appropriate amount of water in DMSO could suppress some side reactions while preserving the reactivity of mannose dehydration. Mannose showed a comparable reactivity to fructose in the employed catalytic system. The studied system was also effective in the conversion of di/trisaccharides such as cellobiose and melezitose into 5-HMF. A number of control experiments with different catalysts and additives were conducted to elucidate the preliminary mechanism.
\end{abstract}

\section{Introduction}

5-Hydroxymethylfurfural (5-HMF) represents a versatile biobased platform compound. ${ }^{1}$ 5-HMF can be refined into varieties of high value added fine chemicals and transport fuels through oxidation, reduction, etherification, amination, alkylation and condensation..$^{2-8}$ The synthesis of 5-HMF from carbohydrates is consistent with the scope of sustainable development in the future, and thus, 5-HMF has attracted widespread attention. ${ }^{1}$ 5HMF was recognized as an important and potential platform compound as early as $1990 .{ }^{9}$ Entering the 21 st century, the pioneering work reported by Dumesic et al. and Zhang et al., respectively, has set off new studies toward the conversion of biomass into 5-HMF worldwide. ${ }^{10,11}$

Fructose and glucose are the most common carbohydrates for 5 -HMF production. ${ }^{1}$ Fructose exists in a considerable proportion of furanoses (e.g. $\alpha$ - and $\beta$-furanose account for

${ }^{a}$ College of Chemical Engineering, Shenyang University of Chemical Technology, Shenyang, Liaoning, 110142, China. E-mail: jiasongyan@126.com; Tel: +86-24-89386342

${ }^{b}$ State Key Laboratory of Catalysis, Dalian National Laboratory for Clean Energy, Dalian Institute of Chemical Physics, Chinese Academy of Sciences, Dalian, Liaoning, 116023, China

† Electronic supplementary information (ESI) available. See DOI: $10.1039 / \mathrm{c} 7 \mathrm{ra07803j}$ $\sim 31.5 \%$ of fructose at equilibrium in water at $\left.31{ }^{\circ} \mathrm{C}\right),{ }^{12}$ which are proposed as the active species, ${ }^{13}$ so fructose can be readily converted into 5-HMF with various catalysts, such as mineral acids, metal salts, zeolites, ionic liquids and other functionalized materials. ${ }^{14-19}$ By contrast, glucose remains recalcitrant to most catalysts used for fructose conversion. Glucose almost exists in the form of $\alpha$ - and $\beta$-pyranose. ${ }^{12}$ As shown in Scheme 1 , it is generally accepted that glucose undergoes a two-step tandem reaction to produce 5-HMF (isomerization of glucose into fructose and dehydration of fructose into 5-HMF). ${ }^{11,20,21}$ The representative catalysts for glucose conversion typically include an active metal center (e.g. $\mathrm{Cr}, \mathrm{Sn}, \mathrm{Al}, \mathrm{Ge})$, which is mainly used in the form of metal salt. ${ }^{11,13,22-24}$ As a result of the above work, some related polymer feedstocks such as inulin and cellulose have been exploited as well. ${ }^{25-28}$

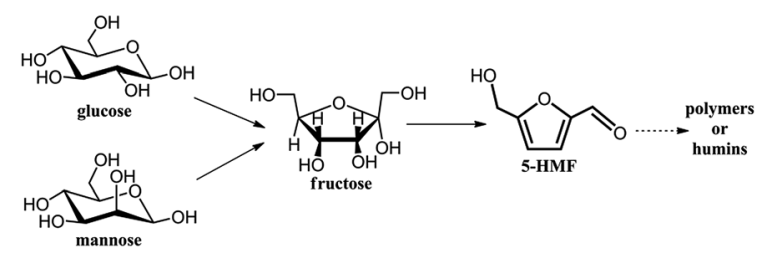

Scheme 1 Schematic path on the conversion of glucose and mannose into 5-HMF. 
In addition to fructose and glucose, other underused sugars receive far less attention in the aspect of 5-HMF synthesis, although some of them have considerable reserves in nature. As shown in Scheme 1, mannose is the C-2 epimer of glucose. Mannose is one of the major hexoses in hemicellulose. ${ }^{29}$ For instance, mannose can account for $\sim 10 \%$ of the dry weight of pine wood. ${ }^{30}$ Efficient conversion of mannose into 5-HMF would provide reference for the utilization of hemicellulose. However, information on such conversion still remains limited at present. Binder et al. previously demonstrated that mannose showed a similar reactivity to that of glucose in $\mathrm{N}, \mathrm{N}$-dimethylacetamide (DMA)-lithium chloride/bromide ( $\mathrm{LiCl} / \mathrm{LiBr}$ ) with $\mathrm{CrCl}_{2}$ or $\mathrm{CrCl}_{3}$ as the catalyst. A 5-HMF yield of 69\% was achieved in DMA- $\mathrm{LiBr}$ at $100{ }^{\circ} \mathrm{C}$ after $2 \mathrm{~h} .{ }^{31}$ De et al. obtained a 5 -HMF yield of $45 \%$ from mannose in DMA-LiCl with a $\mathrm{H}$-form $\mathrm{TiO}_{2}$ catalyst at $140{ }^{\circ} \mathrm{C}$ under microwave. ${ }^{32}$ Most recently, Wrigstedt et al. gained a 5 -HMF yield of $69 \%$ in a potassium bromide (aq.) $-\gamma$-valerolactone biphasic system with $\mathrm{CrCl}_{3} \cdot 6 \mathrm{H}_{2} \mathrm{O}$ and Amberlyst-38 at $160{ }^{\circ} \mathrm{C}$ under microwave. ${ }^{33}$ Bhanja et al. synthesized a bifunctionalized mesoporous SBA-15 catalyst which converted mannose into 5-HMF in dimethyl sulfoxide (DMSO) with a yield of $61 \%$ at $135{ }^{\circ} \mathrm{C}$ under microwave. ${ }^{34}$ Flannelly et al. investigated the conversion of mannose and glucose in sulphuric acid solution. Both hexoses underwent comparable conversions with levulinic acid yields of $\sim 45 \%$, a followed product through the hydration of 5-HMF, at $150{ }^{\circ} \mathrm{C}$ after $6 \mathrm{~h} .{ }^{35}$ Guo et al. studied the conversion of mannose in aqueous medium with $\mathrm{Nb}_{4} \mathrm{~W}_{4}$ catalyst at $120{ }^{\circ} \mathrm{C}$, while the 5 -HMF yield was lower than $10 \%{ }^{36}$ The above studies used either complicated system or microwave, and it will still be necessary to develop facile and effective approaches to produce 5-HMF by mannose and other underused sugars.

In this work, we were committed to explore effective approaches to convert mannose into 5-HMF. We employed a series of metal salts and mineral acids as the catalysts. Some aluminum salts showed good catalytic activities in a DMSO/ $\mathrm{H}_{2} \mathrm{O}$ mixed solvent. Some parameters such as water content, catalyst type and loading, reaction temperature, reaction time, feedstock type were investigated in detail. A number of control experiments with different catalysts or simple model compounds were also conducted to facilitate understanding the reaction mechanism.

\section{Experimental}

\subsection{Materials}

D-Mannose (99\%), D-glucose (99\%), D-fructose (99\%), D-melezitose monohydrate (99\%), 5-hydroxymethylfurfural (5-HMF, 99\%), $\mathrm{MnCl}_{2} \cdot 4 \mathrm{H}_{2} \mathrm{O}$ (99\%), $\mathrm{NiCl}_{2} \cdot 6 \mathrm{H}_{2} \mathrm{O}$ (99\%), $\mathrm{FeCl}_{2} \cdot 4 \mathrm{H}_{2} \mathrm{O}$ (99\%), $\mathrm{FeCl}_{3} \cdot 6 \mathrm{H}_{2} \mathrm{O}$ (99\%), $\mathrm{LaCl}_{3} \cdot 7 \mathrm{H}_{2} \mathrm{O}$ (99\%), $\mathrm{CoCl}_{2} \cdot 6 \mathrm{H}_{2} \mathrm{O}$ (99\%), $\mathrm{ZnCl}_{2}$ (99\%), $\mathrm{AlCl}_{3} \cdot 6 \mathrm{H}_{2} \mathrm{O}(98 \%), \mathrm{InCl}_{3} \cdot 4 \mathrm{H}_{2} \mathrm{O}(99 \%), 1,3-$ dihydroxyacetone (97\%) and levulinic acid (99\%) were purchased from Aladdin (China). D-Cellobiose (98\%) and $\mathrm{CuCl}_{2} \cdot 2 \mathrm{H}_{2} \mathrm{O}$ (99\%) were purchased from Alfa Aesar (China). $\mathrm{CrCl}_{3} \cdot 6 \mathrm{H}_{2} \mathrm{O}(98 \%)$ and DL-glyceraldehyde (90\%) were purchased from Sigma-Aldrich (China). $\mathrm{YbCl}_{3} \cdot 6 \mathrm{H}_{2} \mathrm{O}$ (99\%), aluminum trifluoromethanesulfonate $\left(\mathrm{Al}(\mathrm{OTf})_{3}, 99 \%\right)$ and $\mathrm{AlBr}_{3}(99 \%)$ were purchased from Energy Chemical (China). $\mathrm{SnCl}_{4} \cdot 5 \mathrm{H}_{2} \mathrm{O}$ (99\%), $\mathrm{H}_{3} \mathrm{BO}_{3}$ (99\%), $\mathrm{AlCl}_{3}$ (99\%), $\mathrm{Al}\left(\mathrm{NO}_{3}\right)_{3} \cdot 9 \mathrm{H}_{2} \mathrm{O}$ (98\%), $\mathrm{Al}_{2}\left(\mathrm{SO}_{4}\right)_{3} \cdot 18 \mathrm{H}_{2} \mathrm{O}$ (99\%), dimethyl sulfoxide (DMSO, 99\%), $\mathrm{Al}(\mathrm{OH})_{3}$ (99\%), glycerol (99\%) and 1,2-propanediol (99\%) were purchased from Sinopharm (China). Hydrochloric acid ( $\mathrm{HCl}$, $37 \mathrm{wt} \%)$ and sulfuric acid $\left(\mathrm{H}_{2} \mathrm{SO}_{4}, 98 \mathrm{wt} \%\right)$ were provided by a local supplier. All of the commercial chemicals were used as received. Purified water $\left(\mathrm{H}_{2} \mathrm{O}\right)$ with a resistivity of $18.2 \mathrm{M} \Omega \mathrm{cm}$ was produced by an ultra-pure water system (Taoshi Brand, China).

\subsection{Reaction procedure}

Typically, mannose (60 mg), catalyst (10 mol\% to mannose) and solvent $(1 \mathrm{~mL})$ were added into a reaction vial with a magnetic stir bar. The vial was sealed and inserted into a heating block. The mixture was stirred at a speed of $\sim 400 \mathrm{rpm}$ at the reaction temperature. After a specified time, the vial was taken out and immersed in an ice-water bath to quench the reaction. Then, $1 \mathrm{~mL}$ of $\mathrm{H}_{2} \mathrm{O}$ and a certain amount of glycerol (internal standard) were added into the vial. A small amount of reaction mixture was taken out and further diluted with $\mathrm{H}_{2} \mathrm{O}$. All the samples were analyzed by high performance liquid chromatography (HPLC) after filtration.

\subsection{Analysis method}

HPLC was performed on a Shimadzu LC-16 system equipped with a Shimadzu RID-20 refractive index detector and an Agilent Hi-Plex ligand exchange column ( $\mathrm{H}$-form, $300 \times 7.7 \mathrm{~mm}$ ). A $0.005 \mathrm{M}$ aqueous solution of $\mathrm{H}_{2} \mathrm{SO}_{4}$ was used as the mobile phase with a flow rate of $0.65 \mathrm{~mL} \mathrm{~min}^{-1}$. The column and detector temperatures were $65{ }^{\circ} \mathrm{C}$ and $50{ }^{\circ} \mathrm{C}$, respectively. Glycerol was added as the internal standard for quantitative calculations. It should be specified that the retention times of 1,3-dihydroxyacetone and glycerol are overlapped under the analysis conditions, and 1,3-dihydroxyacetone could be an isomerization product from glyceraldehyde. Thus, 1,2-propanediol was used as an alternative internal standard for the control experiments with glyceraldehyde, 1,3-dihydroxyacetone and glycerol. The conversion and product yield data were calculated by mole.

\section{Results and discussion}

\subsection{Catalyst screening test}

Mannose is the C-2 epimer of glucose ${ }^{29}$ implying that a catalyst enabling the conversion of glucose into 5-HMF could be the potential candidate in this work. According to previous report on glucose conversion, ${ }^{11,22,23,37-43}$ a wide range of metal salts and mineral acids were employed as the catalysts for the preliminary test.

Fig. 1 illustrates the results of catalyst screening in DMSO at $130{ }^{\circ} \mathrm{C}$ for $30 \mathrm{~min}$. As shown, the conversion of mannose did not essentially occur in the absence of a catalyst, with very low conversion ( $\sim 5 \%$ ), and no 5- $\mathrm{HMF}$ was detected. $\mathrm{MnCl}_{2} \cdot 4 \mathrm{H}_{2} \mathrm{O}$, $\mathrm{FeCl}_{2} \cdot 4 \mathrm{H}_{2} \mathrm{O}, \mathrm{FeCl}_{3} \cdot 6 \mathrm{H}_{2} \mathrm{O}, \mathrm{CuCl}_{2} \cdot 2 \mathrm{H}_{2} \mathrm{O}, \mathrm{CoCl}_{2} \cdot 6 \mathrm{H}_{2} \mathrm{O}$ and $\mathrm{H}_{3} \mathrm{BO}_{3}$ did not catalyze the formation of 5-HMF, possibly because these 


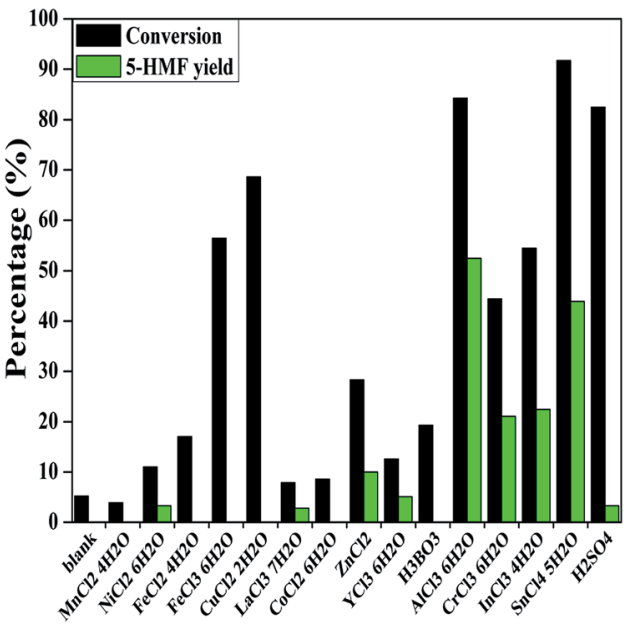

Fig. 1 Conversion of mannose in the presence of different catalysts in DMSO at $130{ }^{\circ} \mathrm{C}$ for $30 \mathrm{~min}$.

catalysts were unable to isomerize mannose into a proper intermediate, such as fructose. Although 5-HMF could be produced by employing $\mathrm{NiCl}_{2} \cdot 6 \mathrm{H}_{2} \mathrm{O}, \mathrm{LaCl}_{3} \cdot 7 \mathrm{H}_{2} \mathrm{O}, \mathrm{ZnCl}_{2}$, $\mathrm{YbCl}_{3} \cdot 6 \mathrm{H}_{2} \mathrm{O}$ and $\mathrm{H}_{2} \mathrm{SO}_{4}$, the 5 -HMF yields were still low. The large difference between mannose conversion and 5-HMF yield over $\mathrm{FeCl}_{3} \cdot 6 \mathrm{H}_{2} \mathrm{O}, \mathrm{CuCl}_{2} \cdot 2 \mathrm{H}_{2} \mathrm{O}$ and $\mathrm{H}_{2} \mathrm{SO}_{4}$ indicated that a significant level of side reactions occurred. The side products were proposed to be undesired oligomers, polymers and humins. ${ }^{44}$

By contrast, $\mathrm{CrCl}_{3} \cdot 6 \mathrm{H}_{2} \mathrm{O}$ and $\mathrm{InCl}_{3} \cdot 4 \mathrm{H}_{2} \mathrm{O}$ led to moderate yields of 5 - $\mathrm{HMF}(\sim 22 \%)$. The reaction with $\mathrm{SnCl}_{4} \cdot 5 \mathrm{H}_{2} \mathrm{O}$ achieved an improved 5-HMF yield ( $44 \%)$. Among the tested catalysts, $\mathrm{AlCl}_{3} \cdot 6 \mathrm{H}_{2} \mathrm{O}$ exhibited the superior catalytic performance with $\sim 84 \%$ conversion and a 5 -HMF yield of $\sim 52 \%$. The anhydrous $\mathrm{AlCl}_{3}$ was also tested, giving very close results to $\mathrm{AlCl}_{3} \cdot 6 \mathrm{H}_{2} \mathrm{O}(\sim 87 \%$ conversion and $\sim 51 \% \quad 5$ - $\mathrm{HMF}$ yield $)$. In consideration of the hydroscopicity of $\mathrm{AlCl}_{3}$, leading to difficulty for weighing, $\mathrm{AlCl}_{3} \cdot 6 \mathrm{H}_{2} \mathrm{O}$ was employed for subsequent studies. As reported, some metal salts (e.g. $\left.\mathrm{CrCl}_{3}, \mathrm{AlCl}_{3}\right)$ may hydrolyze into metal ion species (e.g. $\mathrm{M}(\mathrm{OH})^{2+}$ or $\left.\mathrm{M}(\mathrm{OH})_{2}{ }^{+}\right)$and companion acids during the dehydration of glucose into 5HMF ${ }^{45-47}$ It was proposed that the metal ion species mainly played a role in isomerizing glucose into fructose, while the companion acid catalyzed the subsequent dehydration of fructose into 5 -HMF. ${ }^{45,48}$ The conversion of mannose into $5-\mathrm{HMF}$ is a dehydration process, and the produced water will promote the hydrolysis of metal salts. Accordingly, the latter four metal salts may possess the aforementioned properties during the reaction, leading to the production of 5 -HMF. ${ }^{45-47}$

\subsection{Effect of water content in DMSO}

During the catalyst screening tests, $\mathrm{AlCl}_{3} \cdot 6 \mathrm{H}_{2} \mathrm{O}$ exhibited a poor solubility in DMSO and some $\mathrm{AlCl}_{3} \cdot 6 \mathrm{H}_{2} \mathrm{O}$ precipitation appeared after reaction. The other tested metal salts could dissolve well in DMSO. It is speculated that the undissolved $\mathrm{AlCl}_{3} \cdot 6 \mathrm{H}_{2} \mathrm{O}$ may limit 5-HMF yield. To overcome this problem, we attempted to add an appropriate amount of water as co- solvent. As shown in Fig. S1, $\uparrow$ adding little water obviously improved the dissolution of $\mathrm{AlCl}_{3} \cdot 6 \mathrm{H}_{2} \mathrm{O}$. Therefore, the effect of water content in DMSO was next examined.

Five DMSO $/ \mathrm{H}_{2} \mathrm{O}$ solutions with volume fractions of $1000 / 0$, 950/50, 900/100, 800/200 and 600/400 $\left(\mu \mathrm{L} \mu \mathrm{L}^{-1}\right)$ were employed for this investigation. The molar fractions of water $\left(\chi_{\mathrm{w}}\right)$ in the solutions were calculated to be $0,0.17,0.3,0.5$ and 0.72. Fig. 2 presents $\mathrm{AlCl}_{3} \cdot 6 \mathrm{H}_{2} \mathrm{O}$ catalyzed conversion of mannose in DMSO with different amounts of water at $130{ }^{\circ} \mathrm{C}$. The mannose conversion remained at $81-86 \%$ in the systems of $\chi_{\mathrm{w}} \leq 0.3$, and it slightly decreased to $71 \%$ when $\chi_{\mathrm{w}}$ reached 0.5 . However, the mannose conversion sharply dropped to $17 \%$ with further increasing $\chi_{\mathrm{w}}$ to 0.72 . Because the formation of 5-HMF from mannose is a dehydration reaction, water of course will inhibit such process. However, DMSO/ $\mathrm{H}_{2} \mathrm{O}$ binary mixtures retain DMSO-like properties at $\chi_{\mathrm{w}}<0.5,{ }^{49}$ which could be the reason that relatively high conversions (71-86\%) were obtained in $\mathrm{DMSO} / \mathrm{H}_{2} \mathrm{O}$ of $950 / 50,900 / 100$ and $800 / 200\left(\mu \mathrm{L} \mu \mathrm{L}^{-1}\right)$. The 5HMF yield showed a similar trend as mannose conversion, and it kept at $44-56 \%$ in the systems of $\chi_{\mathrm{w}} \leq 0.5$. A maximum $5-\mathrm{HMF}$ yield of $56 \%$ was obtained in $\mathrm{DMSO} / \mathrm{H}_{2} \mathrm{O}$ of $950 / 50\left(\mu \mathrm{L} \mu \mathrm{L}^{-1}\right)\left(\chi_{\mathrm{w}}\right.$ $=0.17)$. The conversion was also monitored in anhydrous DMSO and DMSO/ $\mathrm{H}_{2} \mathrm{O}$ of $950 / 50\left(\mu \mathrm{L}^{-1}\right)$ with reaction time at $130{ }^{\circ} \mathrm{C}$. As shown in Fig. $\mathrm{S} 2, \uparrow \mathrm{AlCl}_{3} \cdot 6 \mathrm{H}_{2} \mathrm{O}$ and $\mathrm{AlCl}_{3}$ showed close activities in DMSO, of which the conversion rate was a little faster than that in $\mathrm{DMSO} / \mathrm{H}_{2} \mathrm{O}$ of $950 / 50\left(\mu \mathrm{L} \mu \mathrm{L}^{-1}\right)$ within $20 \mathrm{~min}$. Adding water may improve the hydrolysis of $\mathrm{AlCl}_{3}$ $\cdot 6 \mathrm{H}_{2} \mathrm{O}$, but water itself is deleterious to the dehydration of mannose into 5-HMF, accounting for the slower conversion rate in $\mathrm{DMSO} / \mathrm{H}_{2} \mathrm{O}$ of $950 / 50\left(\mu \mathrm{L} \mu \mathrm{L}^{-1}\right)$ within short time. As reported, an appropriate amount of water could suppress some side reactions such as inter- and intra-molecular dehydration of sugar to a certain degree, ${ }^{48}$ leading to an improved 5 -HMF yield of $60 \%$ as shown in Fig. S2. $\dagger$ Fig. S3† showed the chromatograms on the conversion of mannose in DMSO and DMSO $/ \mathrm{H}_{2} \mathrm{O}$ of $950 / 50\left(\mu \mathrm{L} \mu \mathrm{L}^{-1}\right)$ without catalyst at $130{ }^{\circ} \mathrm{C}$ for $1 \mathrm{~h}$. The results

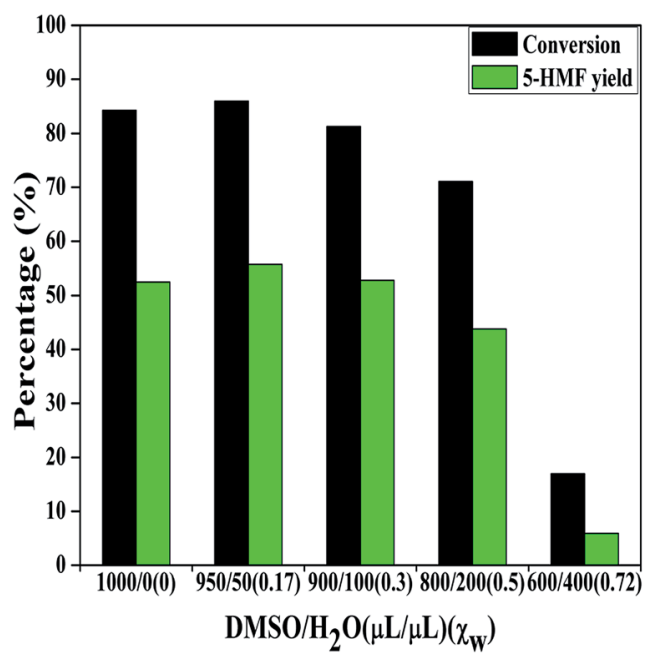

Fig. 2 Catalytic conversion of mannose in varied $\mathrm{DMSO} / \mathrm{H}_{2} \mathrm{O}$ mixed solvents at $130{ }^{\circ} \mathrm{C}$ for $30 \mathrm{~min}$ 
demonstrated that anhydrous DMSO could promote the formation of mannose dimer, while adding a little water suppressed such side reaction. Compared with anhydrous DMSO system, the completely dissolved $\mathrm{AlCl}_{3} \cdot 6 \mathrm{H}_{2} \mathrm{O}$ did not significantly increase the yield of 5-HMF. DMSO/ $\mathrm{H}_{2} \mathrm{O}$ binary mixtures display $\mathrm{H}_{2} \mathrm{O}$-like properties at $\chi_{\mathrm{w}}>0.5$, especially at $\chi_{\mathrm{w}} \geq 0.7,{ }^{50}$ which may lead to the inferior mannose conversion and 5-HMF yield in $\mathrm{DMSO} / \mathrm{H}_{2} \mathrm{O}$ of $600 / 400\left(\mu \mathrm{L} \mu \mathrm{L}^{-1}\right)$. Fig. S4-S6† present the conversion of mannose with $\mathrm{SnCl}_{4} \cdot 6 \mathrm{H}_{2} \mathrm{O}, \mathrm{CrCl}_{3} \cdot 6 \mathrm{H}_{2} \mathrm{O}$ and $\mathrm{InCl}_{3} \cdot 4 \mathrm{H}_{2} \mathrm{O}$ in varied $\mathrm{DMSO} / \mathrm{H}_{2} \mathrm{O}$ solutions, respectively. However, the addition of water significantly suppressed the formation of 5-HMF with increasing $\chi_{\mathrm{w}}$ in the systems. As compared above, $\mathrm{AlCl}_{3} \cdot 6 \mathrm{H}_{2} \mathrm{O}$ was chosen as the catalyst for the subsequent investigations and the $\mathrm{DMSO} / \mathrm{H}_{2} \mathrm{O}$ of 950/50 $\left(\mu \mathrm{L} \mu \mathrm{L}^{-1}\right)$ solution was further employed.

\subsection{Effect of catalyst type and loading}

A number of aluminum salts were then employed to examine their effects on the conversion of mannose into 5-HMF. In order to maintain a $10 \mathrm{~mol} \%$ ratio of aluminum atom to mannose, $5 \mathrm{~mol} \% \mathrm{Al}_{2}\left(\mathrm{SO}_{4}\right)_{3} \cdot 18 \mathrm{H}_{2} \mathrm{O}$ was added herein. As seen in Fig. 3a,
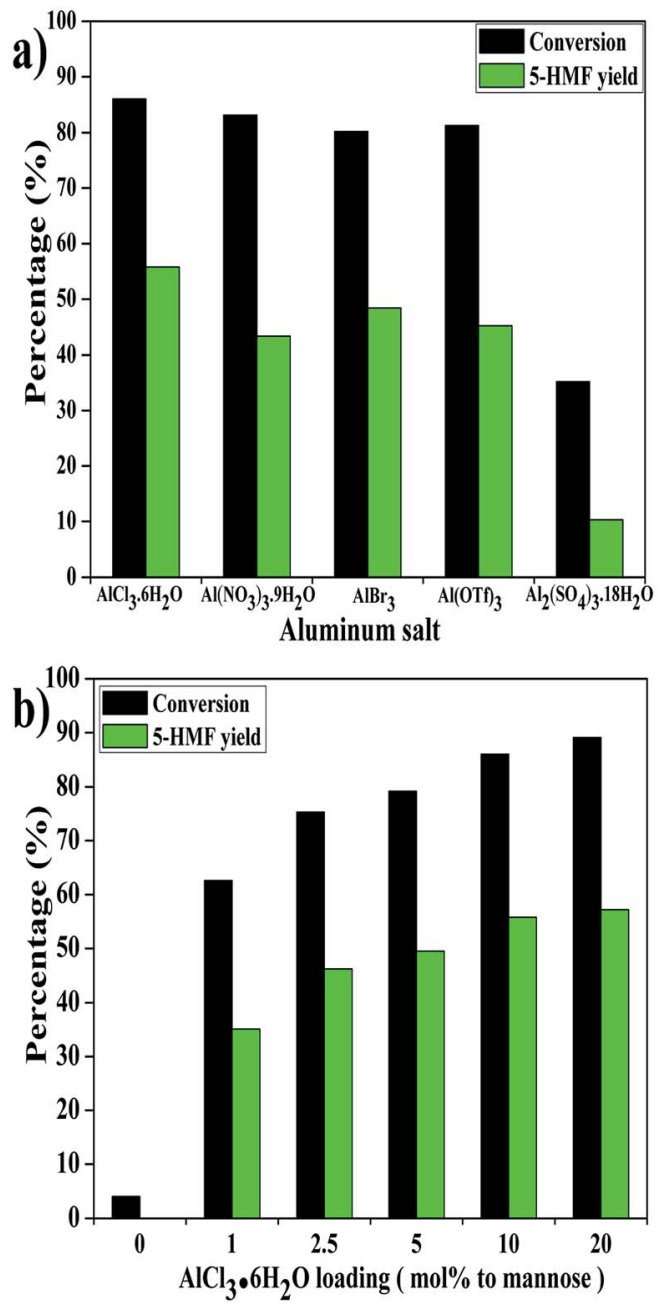

Fig. 3 Effect of aluminum salts (a) and catalyst loadings (b) on the conversion of mannose into $5-\mathrm{HMF}$ at $130{ }^{\circ} \mathrm{C}$ for $30 \mathrm{~min}$. the tested aluminum salts generally worked well for the production of 5-HMF except $\mathrm{Al}_{2}\left(\mathrm{SO}_{4}\right)_{3} \cdot 18 \mathrm{H}_{2} \mathrm{O}$. Average conversion of $\sim 80 \%$ and 5 -HMF yield of $\sim 45 \%$ could be obtained in the presence of $\mathrm{Al}\left(\mathrm{NO}_{3}\right)_{3} \cdot 9 \mathrm{H}_{2} \mathrm{O}, \mathrm{Al}(\mathrm{OTf})_{3}$ and $\mathrm{AlBr}_{3}$, respectively. As compared, no improved 5-HMF yield was achieved with other aluminum salts than $\mathrm{AlCl}_{3} \cdot 6 \mathrm{H}_{2} \mathrm{O}$. These results indicate that the actual active catalyst enabling the conversion of mannose into 5-HMF should be attributed to an aluminum species. One reason accounting for the inferior performance of $\mathrm{Al}_{2}\left(\mathrm{SO}_{4}\right)_{3} \cdot 18 \mathrm{H}_{2} \mathrm{O}$ could be that the active aluminum species as discussed was not effectively produced. Moreover, the steric hindrance of anion should be taken into account as well, while this point needs more in-depth studies.

Fig. 3b illustrates the conversion of mannose with different $\mathrm{AlCl}_{3} \cdot 6 \mathrm{H}_{2} \mathrm{O}$ loadings. As shown in Fig. 3b, no 5-HMF was detected in the absence of a catalyst. The mannose conversion $(\sim 3 \%)$ was lower than that of blank test $(\sim 5 \%)$ in Fig. 1 due to the suppression of water. Only $1 \mathrm{~mol} \% \mathrm{AlCl}_{3} \cdot 6 \mathrm{H}_{2} \mathrm{O}$ loading could lead to $63 \%$ conversion with a 5 -HMF yield of $35 \%$. With increasing catalyst usage, the mannose conversion grew in an upward trend, while the 5-HMF yield was found stagnant at $\mathrm{AlCl}_{3} \cdot 6 \mathrm{H}_{2} \mathrm{O}$ loading $\geq 10 \mathrm{~mol} \%$. Higher usage of catalyst may
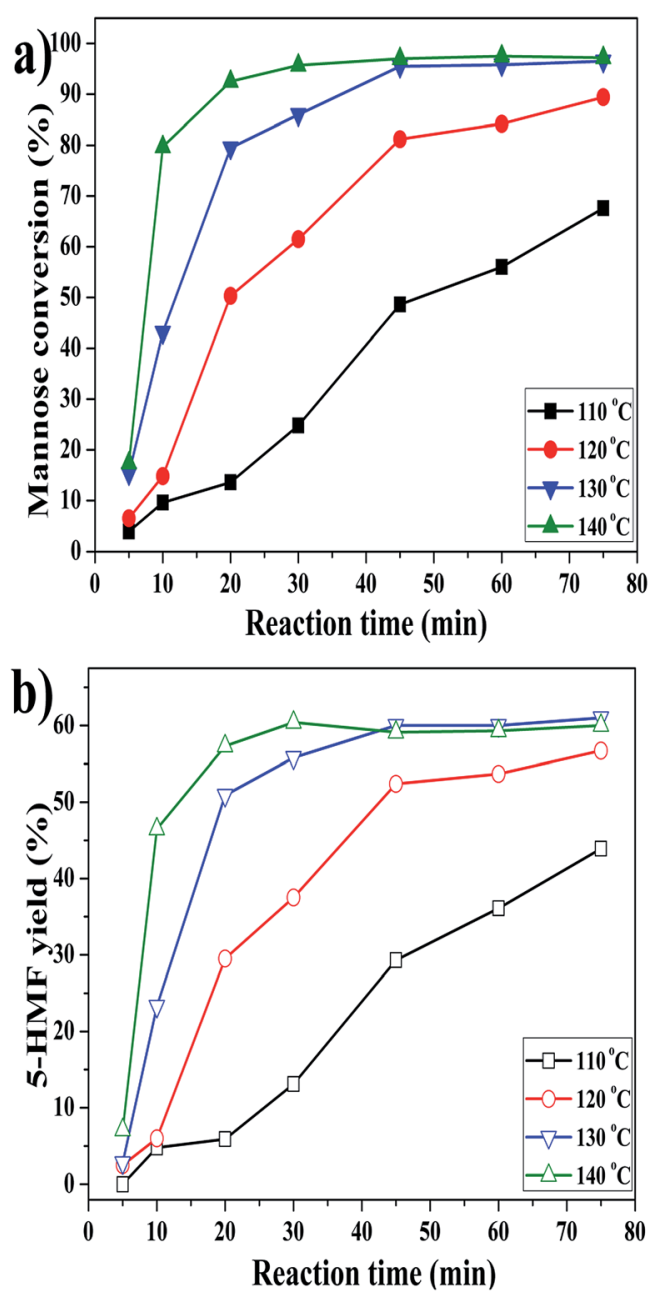

Fig. 4 Effect of reaction temperature and time on the conversion of mannose into 5-HMF in DMSO/ $\mathrm{H}_{2} \mathrm{O}$ of $950 / 50\left(\mu \mathrm{L} \mu \mathrm{L}^{-1}\right)$. 
accelerate more side reactions or 5-HMF degradation, which may explain why 5-HMF yield stopped increasing. Herein, the $\mathrm{AlCl}_{3} \cdot 6 \mathrm{H}_{2} \mathrm{O}$ loading of $10 \mathrm{~mol} \%$ was selected for the next investigation.

\subsection{Effect of reaction temperature and time}

In order to get an optimized 5-HMF yield, the conversion of mannose was monitored as a function of time at different temperatures. As illustrated in Fig. 4, the conversion of mannose could proceed steadily at $110{ }^{\circ} \mathrm{C}$, reaching $68 \%$ with a 5 -HMF yield of $44 \%$ after $75 \mathrm{~min}$. When the reaction was conducted at $130{ }^{\circ} \mathrm{C}$, the mannose conversion and 5-HMF yield almost reached the maximum of $96 \%$ and $60 \%$, respectively, after $45 \mathrm{~min}$. Further elevating temperature to $140{ }^{\circ} \mathrm{C}$ did not improve the 5-HMF yield but obviously shortened reaction time to $\sim 30 \mathrm{~min}$ to achieve the optimum. As mentioned above, dehydration of glucose into 5-HMF is considered to undergo a two-step tandem reaction, including the isomerization of glucose into fructose and the dehydration of fructose into 5HMF. ${ }^{11,20,21}$ Both the isomerization of glucose and dehydration of fructose are endothermic. ${ }^{51,52}$ Mannose should have similar
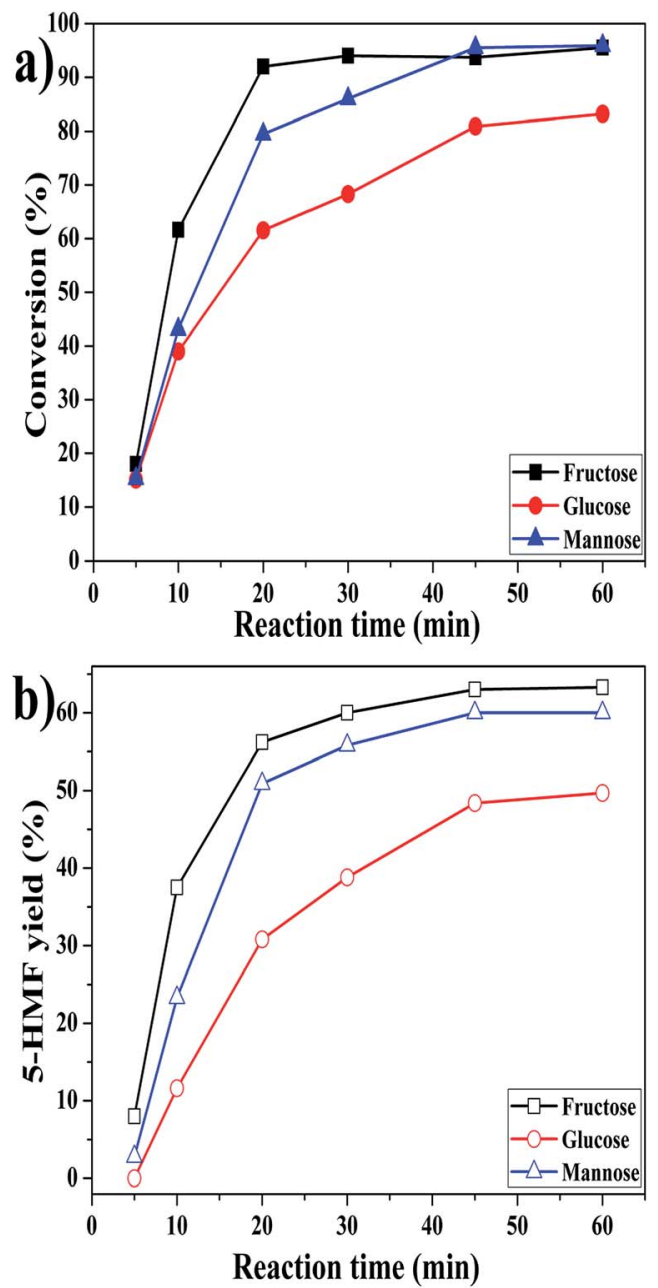

Fig. 5 Comparison on the conversion of mannose, fructose and glucose in $\mathrm{DMSO} / \mathrm{H}_{2} \mathrm{O}$ of $950 / 50\left(\mu \mathrm{L} \mu \mathrm{L}^{-1}\right)$ at $130{ }^{\circ} \mathrm{C}$. thermodynamic properties as glucose based on the fact that it is the C-2 epimer of glucose, which accounts for the significantly accelerated conversion at higher temperatures. The slight decrease of 5-HMF yield at $140{ }^{\circ} \mathrm{C}$ indicated that 5 -HMF could degrade after long time. Moreover, since it is difficult to separate either catalyst or 5-HMF from the homogeneous system, the catalyst circulation test is outside the scope of this work at present.

\subsection{Comparison with other saccharides}

Fructose and glucose are the isomers of mannose, while both of the two saccharides are the most common carbohydrates for 5HMF production. We then compared the reactivity of mannose, fructose and glucose. Fig. 5 presents the reactivity comparison in $\mathrm{DMSO} / \mathrm{H}_{2} \mathrm{O}$ of $950 / 50\left(\mu \mathrm{L} \mu \mathrm{L}^{-1}\right)$ with $\mathrm{AlCl}_{3} \cdot 6 \mathrm{H}_{2} \mathrm{O}$ catalyst at $130{ }^{\circ} \mathrm{C}$. As shown, fructose exhibited the fastest reaction rate with $92 \%$ conversion and 56\% 5-HMF yield after only $20 \mathrm{~min}$, which was consistent with that reported by Guo et al. ${ }^{36}$ However, mannose showed almost comparable conversion and 5-HMF yield to fructose with extending a bit of time.

Disaccharide and trisaccharide were also tested in the system. Fig. 6 illustrates the production of 5-HMF from cellobiose and melezitose over time at $130{ }^{\circ} \mathrm{C}$. Both cellobiose and melezitose produced 5-HMF steadily, achieving a yield of $46 \%$ and 54\%, respectively, after $120 \mathrm{~min}$. The 5-HMF formation from di/trisaccharide was slower than that from monosaccharide, because the former feedstocks needed to be hydrolyzed first. In addition, melezitose can be partially hydrolyzed to glucose and turanose, the latter of which is an isomer of sucrose. ${ }^{53}$ As reported, sucrose had a superior reactivity to cellobiose ${ }^{34,54}$ which may be one reason that melezitose showed a better performance than cellobiose.

\subsection{Mechanistic insights}

A number of control experiments were conducted to get some mechanistic insights on the catalytic conversion of mannose.

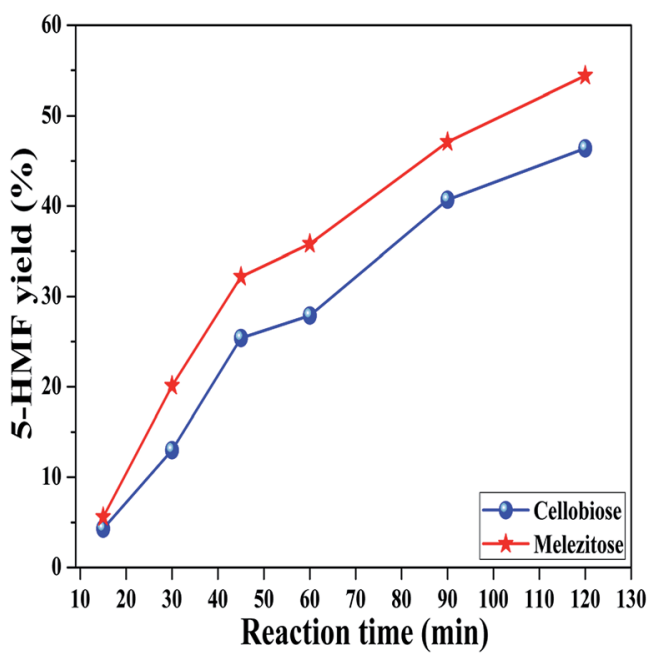

Fig. 6 The production of 5-HMF from cellobiose and melezitose in DMSO/ $\mathrm{H}_{2} \mathrm{O}$ of $950 / 50\left(\mu \mathrm{L} \mu \mathrm{L}^{-1}\right)$ at $130{ }^{\circ} \mathrm{C}$. 
Table 1 Results on the control experiments ${ }^{a}$

\begin{tabular}{|c|c|c|c|c|}
\hline Entry & Catalyst & Additive $^{d}$ & $\begin{array}{l}\text { Conversion } \\
(\%)\end{array}$ & $\begin{array}{l}\text { 5-HMF yield } \\
(\%)\end{array}$ \\
\hline 1 & $\mathrm{AlCl}_{3} \cdot 6 \mathrm{H}_{2} \mathrm{O}$ & None & 80 & 51 \\
\hline $2^{b}$ & $\mathrm{HCl}$ & None & 48 & 6 \\
\hline 3 & $\mathrm{Al}(\mathrm{OH})_{3}$ & None & 5 & 0 \\
\hline $4^{c}$ & $\mathrm{HCl}+\mathrm{Al}(\mathrm{OH})_{3}$ & None & 47 & 5 \\
\hline 5 & $\mathrm{AlCl}_{3} \cdot 6 \mathrm{H}_{2} \mathrm{O}$ & $\mathrm{HCl}(10 \mathrm{~mol} \%)$ & $46 / 68^{e}$ & $25 / 38^{e}$ \\
\hline 6 & $\mathrm{AlCl}_{3} \cdot 6 \mathrm{H}_{2} \mathrm{O}$ & $\mathrm{HCl}(20 \mathrm{~mol} \%)$ & $50 / 71^{e}$ & $15 / 26^{e}$ \\
\hline 7 & $\mathrm{AlCl}_{3} \cdot 6 \mathrm{H}_{2} \mathrm{O}$ & $\mathrm{HCl}(30 \mathrm{~mol} \%)$ & $50 / 66^{e}$ & $11 / 17^{e}$ \\
\hline 8 & $\mathrm{AlCl}_{3} \cdot 6 \mathrm{H}_{2} \mathrm{O}$ & $\begin{array}{l}\text { Glycerol } \\
(100 \mathrm{~mol} \%)\end{array}$ & 80 & 52 \\
\hline 9 & $\mathrm{AlCl}_{3} \cdot 6 \mathrm{H}_{2} \mathrm{O}$ & $\begin{array}{l}\text { Glyceraldehyde } \\
(100 \mathrm{~mol} \%)\end{array}$ & 56 & 36 \\
\hline 10 & $\mathrm{AlCl}_{3} \cdot 6 \mathrm{H}_{2} \mathrm{O}$ & $\begin{array}{l}\text { Dihydroxyacetone } \\
(100 \mathrm{~mol} \%)\end{array}$ & 51 & 32 \\
\hline
\end{tabular}

${ }^{a}$ Conditions: $60 \mathrm{mg}$ of mannose with catalyst (10 mol\% to mannose) was added into total $1 \mathrm{~mL}$ of $\mathrm{DMSO} / \mathrm{H}_{2} \mathrm{O}\left(950 / 50,\left(\mu \mathrm{L} \mu \mathrm{L}^{-1}\right)\right)$ mixed solvent and heated at $130{ }^{\circ} \mathrm{C}$ for $20 \mathrm{~min} .{ }^{b} 30 \mathrm{~mol} \%$ (to mannose) $\mathrm{HCl}$ was added. ${ }^{c} 30 \mathrm{~mol} \%$ (to mannose) $\mathrm{HCl}$ and $10 \mathrm{~mol} \%$ (to mannose) $\mathrm{Al}(\mathrm{OH})_{3}$ were added. ${ }^{d}$ The number in the brackets represents the dosage of additive (with respect to mannose by mol). ${ }^{e}$ The results were obtained after $30 \mathrm{~min}$.

Due to the existence of water, $\mathrm{AlCl}_{3} \cdot 6 \mathrm{H}_{2} \mathrm{O}$ may undergo hydrolysis into $\mathrm{HCl}$, aluminum complexes and $\mathrm{Al}(\mathrm{OH})_{3}$. To clarify which component catalyzed the conversion, both $\mathrm{HCl}$ and $\mathrm{Al}(\mathrm{OH})_{3}$ were tested as the catalyst, respectively. It was assumed that $\mathrm{AlCl}_{3} \cdot 6 \mathrm{H}_{2} \mathrm{O}$ (10 mol\% to mannose) completely hydrolyzed, then the amount of formed $\mathrm{HCl}$ should be $30 \mathrm{~mol} \%$ to mannose. As listed in Table 1 (entry 2), $\mathrm{HCl}$ promoted the conversion of mannose. However, both $\mathrm{HCl}$ and $\mathrm{Al}(\mathrm{OH})_{3}$ were inactive to the formation of 5-HMF (entries 2 and 3). Vlachos et al. and $\mathrm{Hu}$ et al. demonstrated that $\mathrm{AlCl}_{3}$ could hydrolyze into an active aluminum complex, $\mathrm{Al}(\mathrm{OH})^{2+}$ or $\mathrm{Al}(\mathrm{OH})_{2}{ }^{+}$, which played a role in isomerizing glucose ${ }^{45-47}$ As a result, the active aluminium complex was also proposed to be the key species for converting mannose into 5-HMF. As given in entry 4, the performance of mannose conversion appeared to be similar to the one with $\mathrm{HCl}$ alone, possibly because the active aluminium complex was not formed to an appreciable extent under this condition. Partial hydrolysis of $\mathrm{AlCl}_{3} \cdot 6 \mathrm{H}_{2} \mathrm{O}$ could produce $\mathrm{HCl}$ and aluminum complexes as the products. As seen in entries 57 (Table 1), the 5-HMF yield significantly decreased with increasing the usage of $\mathrm{HCl}$, even though the reaction time was extended. Adding $\mathrm{HCl}$ could suppress the hydrolysis of $\mathrm{AlCl}_{3}$ $\cdot 6 \mathrm{H}_{2} \mathrm{O}$, leading to less aluminum complexes, which further verified that aluminum complexes such as $\mathrm{Al}(\mathrm{OH})^{2+}$ or $\mathrm{Al}(\mathrm{OH})_{2}{ }^{+}$ should be the actual active catalyst.

Zhang et al. indicated that the open chain glucose could be considered as a glyceraldehyde attached to a glycerol. ${ }^{11}$ The catalyst may coordinate with the glyceraldehyde subunit of glucose to achieve its isomerization into fructose. ${ }^{11,55}$ Because mannose is the C-2 epimer of glucose, likewise, we think that it is comprised of glyceraldehyde and glycerol subunits. Then, both glyceraldehyde and glycerol were employed as the additives for mannose conversion. As shown in entries 8 and 9
(Table 1), glycerol did not substantially affect the conversion of mannose as compared with entry 1 . However, glyceraldehyde did suppress the formation of 5-HMF, indicating that the catalyst coordinated with the glyceraldehyde part of mannose. 1,3-Dihydroxyacetone could be produced as an isomerization product from glyceraldehyde. Next, 1,3-dihydroxyacetone was also tested as an additive. As shown in entry 10 (Table 1), 1,3dihydroxyacetone suppressed the production of 5-HMF as well. As mentioned above, fructose can also be considered as a 1,3dihydroxyacetone attached to a glycerol. This result may imply that catalyst promote the conversion of fructose, derived from mannose isomerization, by interacting with 1,3-dihydroxyacetone subunit of fructose.

\section{Conclusions}

In this work, we demonstrated that mannose could be effectively converted into $5-\mathrm{HMF}$ in a $\mathrm{DMSO} / \mathrm{H}_{2} \mathrm{O}$ mixed solvent under mild conditions. $\mathrm{AlCl}_{3} \cdot 6 \mathrm{H}_{2} \mathrm{O}$ exhibited the superior activity among the tested catalysts. Adding an appropriate amount of water in DMSO can suppress some side reactions while preserving the reactivity of mannose dehydration. Mannose showed a comparable reactivity to that of fructose in this catalytic system. A maximum 5-HMF yield of $60 \%$ could be obtained at $130{ }^{\circ} \mathrm{C}$ within $45 \mathrm{~min}$. The studied system was also effective for the conversion of other di/trisaccharides into 5HMF. An active aluminum species from the hydrolysis of $\mathrm{AlCl}_{3} \cdot 6 \mathrm{H}_{2} \mathrm{O}$ was turned out to play a key role in converting mannose into 5-HMF. The active aluminum species primarily interacted with the glyceraldehyde subunit of mannose and 1,3dihydroxyacetone subunit of fructose to achieve the final formation of 5-HMF. Mannose is a major sugar component of hemicellulose. The results provided herein will offer useful information on the valorization of hemicellulose and even lignocellulose in the future.

\section{Acknowledgements}

The work was supported by the Natural Science Foundation of Liaoning Province (China) (No. 2015020633), Project of Education Department of Liaoning Province (China) (No. L2015421), the National Natural Science Foundation of China (No. 21306186).

\section{References}

1 R. van Putten, J. C. van der Waal, E. de Jong, C. B. Rasrendra, H. J. Heeres and J. G. de Vries, Chem. Rev., 2013, 113, 14991597.

2 W. Gong, K. Zheng and P. Ji, RSC Adv., 2017, 7, 34776-34782.

3 Z. Xu, P. Yan, H. Li, K. Liu, X. Liu, S. Jia and Z. C. Zhang, ACS Catal., 2016, 6, 3784-3788.

4 Z. Wang and Q. Chen, Green Chem., 2016, 18, 5884-5889.

5 Z. Xu, P. Yan, W. Xu, S. Jia, Z. Xia, B. Chung and Z. C. Zhang, RSC Adv., 2014, 4, 59083-59087.

6 H. Li, Z. Xu, P. Yan and Z. C. Zhang, Green Chem., 2017, 19, $1751-1756$. 
7 Q. Deng, J. Xu, P. Han, L. Pan, L. Wang, X. Zhang and J. Zou, Fuel Process. Technol., 2016, 148, 361-366.

8 P. Han, G. Nie, J. Xie, X. E, L. Pan, X. Zhang and J. Zou, Fuel Process. Technol., 2017, 163, 45-50.

9 B. F. M. Kuster, Starch/Staerke, 1990, 42, 314-321.

10 Y. Román-Leshkov, J. N. Chheda and J. A. Dumesic, Science, 2006, 312, 1933-1937.

11 H. Zhao, J. E. Holladay, H. Brown and Z. C. Zhang, Science, 2007, 316, 1597-1600.

12 S. J. Angyal, Adv. Carbohydr. Chem. Biochem., 1984, 42, 63-65.

13 Y. J. Pagán-Torres, T. Wang, J. M. R. Gallo, B. H. Shanks and J. A. Dumesic, ACS Catal., 2012, 2, 930-934.

14 D. Garcés, E. Díaz and S. Ordóñez, Ind. Eng. Chem. Res., 2017, 56, 5221-5230.

15 F. N. D. C. Gomes, F. M. T. Mendes and M. M. V. M. Souza, Catal. Today, 2017, 279, 296-304.

16 X. Zhou, Z. Zhang, B. Liu, Q. Zhou, S. Wang and K. Deng, J. Ind. Eng. Chem., 2014, 20, 644-649.

17 Z. Ma, H. Hu, Z. Sun, W. Fang, J. Zhang, L. Yang, Y. Zhang and L. Wang, ChemSusChem, 2017, 10, 1669-1674.

18 H. Guo, X. Qi, Y. Hiraga, T. M. Aida and R. L. Smith Jr, Chem. Eng. J., 2017, 314, 508-514.

19 W. Li, T. Zhang, H. Xin, M. Su, L. Ma, H. Jameel, H. Chang and G. Pei, RSC Adv., 2017, 7, 27682-27688.

20 Y. Zhang, E. A. Pidko and E. J. M. Hensen, Chem.-Eur. J., 2011, 17, 5281-5288.

21 E. A. Pidko, V. Degirmenci, R. A. van Santen and E. J. M. Hensen, Angew. Chem., Int. Ed., 2010, 49, 2530-2534.

22 S. Hu, Z. Zhang, J. Song, Y. Zhou and B. Han, Green Chem., 2009, 11, 1746-1749.

23 Y. Yang, C. Hu and M. M. Abu-Omar, J. Mol. Catal. A: Chem., 2013, 376, 98-102.

24 Z. Zhang, Q. Wang, H. Xie, W. Liu and Z. K. Zhao, ChemSusChem, 2011, 4, 131-138.

25 C. Antonetti, M. Melloni, D. Licursi, S. Fulignati, E. Ribechini, S. Rivas, J. C. Parajó, F. Cavani and A. M. R. Galletti, Appl. Catal., B, 2017, 206, 364-377.

26 C. Antonetti, A. M. R. Galletti, S. Fulignati and D. Licursi, Catal. Commun., 2017, 97, 146-150.

27 C. Chiappe, M. J. R. Douton, A. Mezzetta, C. S. Pomelli, G. Assanelli and A. R. de Angelis, ACS Sustainable Chem. Eng., 2017, 5, 5529-5536.

28 H. Shirai, S. Ikeda and E. W. Qian, Fuel Process. Technol., 2017, 159, 280-286.

29 https:/en.wikipedia.org/wiki/Hemicellulose, accessed on 2017.07.07.

30 T. Marzialetti, M. B. V. Olarte, C. Sievers, T. J. C. Hoskins, P. K. Agrawal and C. W. Jones, Ind. Eng. Chem. Res., 2008, 47, 7131-7140.

31 J. B. Binder, A. V. Cefali, J. J. Blank and R. T. Raines, Energy Environ. Sci., 2010, 3, 765-771.
32 S. De, S. Dutta, A. K. Patra, B. S. Rana, A. K. Sinha, B. Saha and A. Bhaumik, Appl. Catal., A, 2012, 435-436, 197-203.

33 P. Wrigstedt, J. Keskiväli and T. Repo, RSC Adv., 2016, 6, 18973-18979.

34 P. Bhanja, A. Modak, S. Chatterjee and A. Bhaumik, ACS Sustainable Chem. Eng., 2017, 5, 2763-2773.

35 T. Flannelly, M. Lopes, L. Kupiainen, S. Dooley and J. J. Leahy, RSC Adv., 2016, 6, 5797-5804.

36 J. Guo, S. Zhu, Y. Cen, Z. Qin, J. Wang and W. Fan, Appl. Catal., B, 2017, 200, 611-619.

37 T. Deng, X. Cui, Y. Qi, Y. Wang, X. Hou and Y. Zhu, Chem. Commun., 2012, 48, 5494-5496.

38 T. Ståhlberg, M. G. Sørensen and A. Riisager, Green Chem., 2010, 12, 321-325.

39 Y. Shen, J. Sun, Y. Yi, B. Wang, F. Xu and R. Sun, J. Mol. Catal. A: Chem., 2014, 394, 114-120.

40 T. Ståhlberg, S. Rodriguez-Rodriguez, P. Fristrup and A. Riisager, Chem.-Eur. J., 2011, 17, 1456-1464.

41 F. Tao, H. Song, J. Yang and L. Chou, Carbohydr. Polym., 2011, 85, 363-368.

42 F. Tao, H. Song and L. Chou, J. Mol. Catal. A: Chem., 2012, 357, 11-18.

43 Z. Ding, J. Shi, J. Xiao, W. Gu, C. Zheng and H. Wang, Carbohydr. Polym., 2012, 90, 792-798.

44 J. Heltzel, S. K. R. Patil and C. R. F. Lund, in Reaction Pathways and Mechanisms in Thermocatalytic Biomass Conversion II, ed. M. Schlaf and Z. C. Zhang, Springer, 2016, pp. 105-118.

45 V. Choudhary, S. H. Mushrif, C. Ho, A. Anderko, V. Nikolakis, N. S. Marinkovic, A. I. Frenkel, S. I. Sandler and D. G. Vlachos, J. Am. Chem. Soc., 2013, 135, 3997-4006.

46 J. Tang, X. Guo, L. Zhu and C. Hu, ACS Catal., 2015, 5, 50975103.

47 J. Tang, L. Zhu, X. Fu, J. Dai, X. Guo and C. Hu, ACS Catal., 2017, 7, 256-266.

48 S. Jia, Z. Xu and Z. C. Zhang, Chem. Eng. J., 2014, 254, 333339.

49 Y. Koga, Y. Kasahara, K. Yoshino and K. Nishikawa, J. Solution Chem., 2001, 30, 885-893.

50 N. Zhang, W. Li, C. Chen and J. Zuo, Comput. Theor. Chem., 2013, 1017, 126-135.

51 Y. B. Tewari, Appl. Biochem. Biotechnol., 1990, 23, 187-203.

52 R. S. Assary, P. C. Redfern, J. R. Hammond, J. Greeley and L. A. Curtiss, J. Phys. Chem. B, 2010, 114, 9002-9009.

53 https://en.wikipedia.org/wiki/Melezitose, accessed on 2017.07.07.

54 Y. Qu, L. Li, Q. Wei, C. Huang, P. Oleskowicz-Popiel and J. Xu, Sci. Rep., 2016, 6, 26067.

55 S. Jia, K. Liu, Z. Xu, P. Yan, W. Xu, X. Liu and Z. C. Zhang, Catal. Today, 2014, 234, 83-90. 